\title{
Pressure effects on surface Mediterranean prokaryotes and biogenic silica dissolution during a diatom sinking experiment
}

\author{
Christian Tamburini ${ }^{1, *}$, Jean Garcin ${ }^{1}$, Gérald Grégori ${ }^{1}$, Karine Leblanc ${ }^{2}$, \\ Peggy Rimmelin ${ }^{2}$, David L. Kirchman ${ }^{3}$ \\ ${ }^{1}$ Laboratoire Microbiologie, Géochimie et Ecologie Marines, UMR 6117 CNRS-INSU, and \\ ${ }^{2}$ Laboratoire d'Océanographie et de Biogéochimie, UMR 6535 CNRS-INSU, Université de la Méditerranée, \\ Centre d'Océanologie de Marseille, Campus de Luminy, Case 901, 13288 Marseille, Cedex 9, France \\ ${ }^{3}$ College of Marine Studies, University of Delaware, Lewes, Delaware 19958, USA
}

\begin{abstract}
This study examined the effect of increasing pressure on biogenic silica dissolution and on prokaryotic assemblages associated with diatom detritus. Experiments were carried out in hyperbaric bottles subjected to a gradual increase in pressure and compared to incubations at atmospheric pressure. To examine only pressure effects and to simulate detritus degradation in the Mediterranean Sea, the incubation temperature was kept constant $\left(13^{\circ} \mathrm{C}\right)$, while pressure was increased by $1.5 \mathrm{MPa}$ $\mathrm{d}^{-1}$, simulating a fall of particles at a sinking rate of $150 \mathrm{~m} \mathrm{~d}^{-1}$ over $8 \mathrm{~d}$. Aminopeptidase activity was significantly lower (nearly 5 -fold) under increasing pressure than under atmospheric pressure conditions. Lower aminopeptidase activity under increasing pressure affected biogenic silica dissolution, at least at the beginning of the incubation, corresponding to a simulated depth of the first $800 \mathrm{~m}$ of the water column. Silicic acid regeneration rates were very low $\left(0.07 \pm 0.02 \mu \mathrm{mol} \mathrm{l}^{-1} \mathrm{~h}^{-1}\right)$ under increasing pressure conditions during the first $4 \mathrm{~d}$ (i.e. between 200 and $800 \mathrm{~m}$ ), while rates were much higher under atmospheric pressure $\left(0.32 \pm 0.05 \mu \mathrm{mol} \mathrm{l}^{-1} \mathrm{~h}^{-1}\right)$. However, orthosilicic acid concentrations in the incubations under increasing pressure approached those of the atmospheric pressure incubations by the end of the experiment. In contrast, the taxonomic composition of prokaryotic communities was not affected by increasing pressure, but the input of fresh diatom detritus led to an increase in the relative abundance of the Cytophago-Flavobacter cluster and $\gamma$-Proteobacteria. These results suggest that hydrostatic pressure affects the function rather than the broad taxonomic structure of prokaryotic communities associated with sinking detrital particles.
\end{abstract}

KEY WORDS: Hydrostatic pressure $\cdot$ Particle sinking $\cdot$ Decomposition processes $\cdot$ Ectoenzymatic activity $\cdot$ Silica dissolution $\cdot$ Prokaryotic diversity $\cdot$ Mesopelagic waters $\cdot$ Bathypelagic waters

\section{INTRODUCTION}

Attached bacteria play an important biogeochemical role in the oceanic carbon flux and are implicated in the remineralization and enzymatic dissolution of particulate organic matter (POM) during its descent through the water column (Cho \& Azam 1988, Turley \& Mackie 1994, 1995). Remarkably little is known about the composition of POM as it sinks through mesopelagic and bathypelagic waters (Wakeham et al.
1997, Hedges et al. 2000). It is known that a large component of the sinking flux consists of diatoms, which dominate phytoplankton communities at specific times of the year in many oceanic systems (Honjo et al. 1995, Smith et al. 1996, Tréguer \& Pondaven 2000).

The fate of sinking biogenic mineral particles depends on the remineralization of the organic matrix, as well as on the dissolution of the mineral matrix. Both processes could be mediated by microbial activities. Milliman et al. (1999), for instance, suggested the exis- 
tence of a biologically mediated dissolution of calcium carbonate. Other studies demonstrated that bacteria accelerate diatom opal dissolution by colonizing and enzymatically degrading the organic matrix of diatom frustules (Bidle \& Azam 1999, 2001). Bidle et al. (2002) found that the control by temperature of marine bacteria degrading diatom detritus strongly influences the coupling of biogenic silica and organic carbon preservation.

Recently, based on data from the equatorial Pacific, Armstrong et al. (2002) and Francois et al. (2002) argued that fluxes of ballast minerals (biogenic silica or diatom opal, carbonate biominerals, and dust) determine deep-water particulate organic carbon (POC) fluxes, so that a mechanism-based model of POC export must simultaneously model both POC and the fluxes of ballast minerals. According to these models, the deep-water fluxes of organic carbon are directly proportional to the total fluxes of ballast minerals at these depths. Therefore, the ability to quantify correctly the remineralization processes at each depth in the water column is critical. This is especially necessary for using models of POC remineralization reliably. In fact, models of POC mineralization, such as that of Martin et al. (1987), assume that there is a tight quantitative relationship between export production and the amount of carbon reaching the sediments. If so, the organic carbon flux can be predicted at any depth solely from the carbon flux at some near-surface depth.

In spite of numerous studies showing that decompression of deep samples may lead to underestimates of prokaryotic activity rates (ZoBell 1970, Tabor et al. 1981, Jannasch \& Wirsen 1982, Bianchi \& Garcin 1993, Deming 2001, Tamburini et al. 2002, 2003), degradation rates of sinking particles are usually measured under atmospheric pressure (Bidle \& Azam 1999, 2001, Sempéré et al. 2000, Bidle et al. 2002, Panagiotopoulos et al. 2002). As a consequence, current biogeochemical models of the silica cycle do not take into account the possible effects of hydrostatic pressure on decomposition during sinking. These models are based on the assumption that biogenic silica dissolution is controlled by temperature, zooplankton grazing, and diatom aggregation rate (Tréguer et al. 1989, Nelson et al. 1995, Dugdale \& Wilkerson 1998), and implicitly assume that pressure has no effect.

The purpose of this study was to examine the effect of a gradual increase in pressure on surface prokaryotic communities enriched with axenic diatom detritus. Parallel incubations were set up under controlled pressure conditions, and prokaryotic ectoenzymatic activity and dissolution of biogenic silica rates, as well as the structure of the prokaryotic communities, were monitored over time. The experiments were based on the experimental design of Bidle \& Azam (1999, 2001) and Bidle et al. (2002, 2003), but were modified to study pressure effects.

\section{MATERIALS AND METHODS}

Synthesis of diatom detritus from Thalassiosira weissflogii. An axenic culture of $T$. weissflogii (CCMP 1336) was obtained from the Provasoli Guillard Center for Culture of Marine Phytoplankton (West Boothbay Harbor, Maine, USA) and grown in $f / 2$ medium (Guillard 1975). This culture was verified by microscopy to be axenic. Fresh diatom detritus was obtained from cell suspensions by rapidly freeze-thawing (dry ice/ethanol bath followed by a $55^{\circ} \mathrm{C}$ water bath) diatom cells for 7 cycles. The detritus was stored at $-20^{\circ} \mathrm{C}$ until further use. A fresh diatom detritus sample was diluted with $0.8 \mu \mathrm{m}$ filtered seawater to obtain a final concentration of $400 \mu \mathrm{g}$ POC $\mathrm{l}^{-1}$ in order to mimic a decaying diatom bloom. This concentration corresponded to a cell density of $10^{3}$ to $10^{4}$ cells $\mathrm{ml}^{-1}$.

Incubation under increasing pressure. Two experiments were carried out in January 2002 and February 2004. Mediterranean seawater $\left(13^{\circ} \mathrm{C}\right)$ was collected off Marseille, France, above the Cassidaigne Trench at $200 \mathrm{~m}$ depth (February 2002) and at the surface (January 2004). Natural prokaryotic assemblages were obtained by gentle filtration through $0.8 \mu \mathrm{m}$ polycarbonate filters. Incubations under increasing pressure were carried out in hyperbaric bottles, which can reproduce the increase in hydrostatic pressure observed in the ocean with increasing depth. These high-pressure bottles were the same as the ones used in previous studies to obtain undecompressed deep-sea water samples (Bianchi et al. 1999, Tamburini et al. 2003). The $500 \mathrm{ml}$ high-pressure bottles were first autoclaved, filled with seawater containing the natural bacterial assemblage, and subsequently amended with the fresh diatom detritus mixture. Diatom detritus was kept in suspension by rotation (half-revolution each minute) using a specialized apparatus designed for high-pressure bottles. The incubation was at $13^{\circ} \mathrm{C}$, corresponding to the average temperature of the water column below $200 \mathrm{~m}$ in the Mediterranean Sea. One bottle was kept at atmospheric pressure, while a second bottle was subjected to a pressure increase of $1.5 \mathrm{MPa} \mathrm{d}^{-1}$, to simulate a sinking rate of $150 \mathrm{~m} \mathrm{~d}^{-1}$. For the first experiment (January 2002), pressure was increased by $1.5 \mathrm{MPa} \mathrm{d}^{-1}$. For the second one (February 2004), pressure was increased continuously by a programmable computer-driven system. The experimental system will be described in detail elsewhere (C. Tamburini et al. unpubl. data). According to laboratory and field studies (Alldredge \& Gotschalk 1988), the sinking speed used in these experiments is applicable to mid-density particles such 
as those from diatoms or clay aggregates. Settling velocities of marine snow range from 1 to $370 \mathrm{~m} \mathrm{~d}^{-1}$, depending on the composition, size, and abundance of the particles, as well as on the hydrodynamic features of the environment. Two types of controls were performed: (1) one with sterilized seawater, i.e. without any prokaryotes, but with diatom detritus, and (2) another with the natural prokaryote assemblage, but without any added diatom detritus.

Every $2 \mathrm{~d}$, community structure and silicic acid concentrations were sampled in the incubations, while maintaining the pressure conditions of the incubation. To measure total community aminopeptidase activity, $50 \mathrm{ml}$ was transferred to 2 new sterilized high-pressure bottles (one for the atmospheric incubation, the other for the pressurized incubation); for the bottle maintained under atmospheric pressure, transfer and incubation were performed under atmospheric pressure. For the bottle under increasing pressurization, transfer and incubation were performed without any change in pressure. For example, on Day 4, the pressure of the culture under increasing pressure was $8 \mathrm{MPa}$, and transfer and incubation for aminopeptidase activity measurements were done at $8 \mathrm{MPa}$. All incubations were done at in situ temperature $\left(13^{\circ} \mathrm{C}\right)$.

Aminopeptidase activity and silicic acid measurement. The fluorogenic substrate L-leucine-7-amino-4methylcoumarin (Leu-MCA, Sigma Chemical; Chrost 1991) was added at a final concentration of $100 \mu \mathrm{M}$ (Bidle \& Azam 1999, 2001). Ectoenzymatic assays were done over $4 \mathrm{~h}$, and the increase in fluorescence was measured using a Kontron SFM 25 spectrofluorometer (emission and excitation wavelengths at 455/365 nm). Orthosilicic acid $\left[\mathrm{Si}(\mathrm{OH})_{4}\right]$ concentrations were measured using a colorimetric method (Strickland \& Parsons 1972) on a CECIL (CE 1011) spectrophotometer, with a detection limit of $50 \mathrm{nM}$.

Fluorescence in situ hybridization (FISH). The relative abundance of the major prokaryotic groups in natural communities was analyzed by FISH using Cy3labeled oligonucleotides (Table 1). Samples were prepared following the method of Glöckner et al. (1996), as modified by Cottrell \& Kirchman (2000a). Sub-samples were fixed with paraformaldehyde (final concentration $2 \%$ ) and stored overnight at $4^{\circ} \mathrm{C}$. They were sonicated to homogenize them and filtered onto $0.2 \mu \mathrm{m}$ pore size polycarbonate filters (Millipore), rinsed twice with $0.2 \mu \mathrm{m}$ filtered Milli-Q water, and stored at $-20^{\circ} \mathrm{C}$. For each probe, a filter piece (cell-adherent side) was placed on a Parafilm (Pechiney Plastic Packaging)covered glass slide and overlaid with a $30 \mu$ drop of hybridization solution using a final probe concentration of $2.5 \mathrm{ng} \mathrm{hl}^{-1}$. We used the same concentration for unlabeled competitor probes, i.e. unlabeled Gam42a with labeled Bet42a and unlabeled Bet42a with labeled Gam42a (Manz et al. 1992). The glass slides were placed in a closed $50 \mathrm{ml}$ tube and incubated overnight at $42^{\circ} \mathrm{C}$. The hybridization solution contained $0.9 \mathrm{M} \mathrm{NaCl}, 20 \mathrm{mM}$ Tris- $\mathrm{HCl}(\mathrm{pH} 7.4), 5 \mathrm{mM}$ edatic acid (EDTA), $0.01 \%$ sodium dodecyl sulfate (SDS), and the concentration of formamide was determined to achieve the best specificity for the bacterial groups targeted by the different probes (Zarda et al. 1997, Eilers et al. 2000). After hybridization, each piece of filter was transferred into $1 \mathrm{ml}$ of a pre-warmed wash solution containing $20 \mathrm{mM}$ Tris- $\mathrm{HCl}$ (pH 7.4), 10 mM EDTA, $0.01 \%$ SDS, and a concentration of $\mathrm{NaCl}$ appropriate for the probe (Zarda et al. 1997, Eilers et al. 2000). The concentrations of formamide and $\mathrm{NaCl}$ used are listed in Table 1. Filters were mounted using a mixture (4:1) of Citifluor (Ted Pella) and Vectashield (Vector Labs) containing $2 \mu \mathrm{g} \mathrm{ml}^{-1}$ of $4^{\prime}, 6$-diamidino-2phenylindole (DAPI). Cells were counted using semiautomated image analysis on an Olympus Provis AX70 microscope fitted with a Cy3 filter 41007a (Chroma) and a DAPI filter 31000 (Chroma) with a SPOT-RT (Diagnostic Instruments) and with ImagePro Plus (Media Cybernetics) software (Cottrell \& Kirchman 2003).

Table 1. The 16S rRNA-targeted oligonucleotide probes used in this study. FA: formamide

\begin{tabular}{|c|c|c|c|c|c|}
\hline Probe & Sequence $\left(5^{\prime}\right.$ to $\left.3^{\prime}\right)$ of probe & Target organisms & $\begin{array}{c}\% \\
\text { FA }\end{array}$ & $\begin{array}{c}{[\mathrm{NaCl}]} \\
(\mathrm{mM})\end{array}$ & Source \\
\hline Eub338 & GCT GCC TCC CGT AGG AGT & Domain of Bacteria & 30 & 102 & Amann et al. (1990) \\
\hline NegControl & TAG TGA CGC GCT CGA & For non-specific probe binding & 30 & 102 & Karner \& Fuhrman (1997) \\
\hline Alf968 & GGT AAG GTT CTG CGC GTT & Most of $\alpha$-subclass of Proteobacteria & 30 & 102 & Glöckner et al. (1999) \\
\hline Gam42a & GCC TTC CCA CAT CGT TT & $\gamma$-subclass of Proteobacteria & 30 & 102 & Manz et al. (1992) \\
\hline Bet42a & GCC TTC CCA CTT CGT TT & $\beta$-subclass of Proteobacteria & 30 & 102 & Manz et al. (1992) \\
\hline CF319a & TGG TCC GTG TCT CAG TAC & Cytophaga-Flavobacter cluster & 35 & 80 & Manz et al. (1996) \\
\hline Arch915 & GTG CTC CCC CGC CAA TTC CT & Archaea & 20 & 308 & Stahl \& Amann (1991) \\
\hline Cren537 & TGA CCA CTT GAG GTG CTG & Crenarchaea & 20 & 308 & Teira et al. (2004) \\
\hline Eury806 & CAC AGC GTT TAC ACC TAG & Euryarchaea & 20 & 308 & Teira et al. (2004) \\
\hline
\end{tabular}




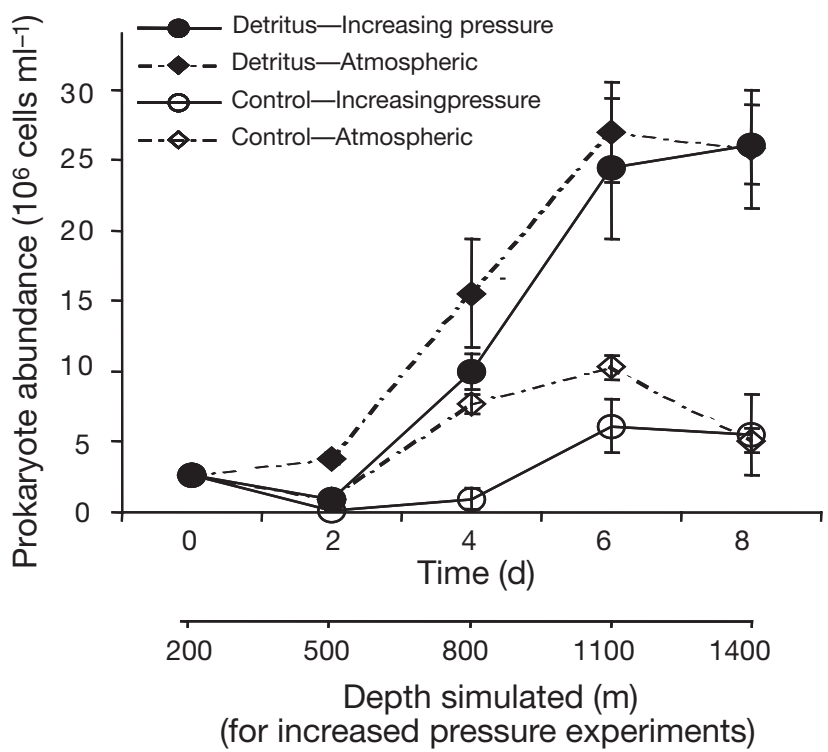

Fig. 1. Prokaryotic abundance over time. Detritus-Increasing pressure: incubation of natural prokaryotic community with fresh diatom detritus under increasing hydrostatic pressure conditions $\left(1.5 \mathrm{MPa} \mathrm{d}^{-1}\right.$ in order to simulate pressure experienced during a sinking fall of $150 \mathrm{~m} \mathrm{~d}^{-1}$ ); DetritusAtmospheric: incubation with detritus at atmospheric pressure; Control-Increasing pressure: incubation without detritus under increasing hydrostatic pressure conditions (1.5 MPa $\left.\mathrm{d}^{-1}\right)_{i}$ Control-Atmospheric: incubation without detritus at atmospheric pressure. Sampling date: February 2004

\section{RESULTS}

\section{Prokaryotic abundance over time}

Prokaryotic abundances increased more quickly and reached higher levels in incubations with diatom detritus than in the control incubation without diatom detritus. Increasing pressure appears to cause a lag in bacterial growth compared to the sample incubated at atmospheric pressure, although growth rates and cell yields in both incubations reached similar levels (Fig. 1). For all incubations, after a lag of $2 \mathrm{~d}$, prokaryotic abundance increased greatly until Day 6 and remained constant until Day 8. The abundance of prokaryotes increased from $2.8 \pm 0.4 \times 10^{6}$ cells ml $^{-1}$ at the beginning of the incubations to $2.6 \pm 0.3 \times 10^{7}$ cells $\mathrm{ml}^{-1}$ at the end of the incubations, with diatom detritus both at atmospheric pressure and under increasing pressure conditions. Without diatom detritus, prokaryotic abundance reached only $5.2 \pm 0.4 \times 10^{6}$ cells ml $^{-1}$ by the end of the incubations.

\section{Aminopeptidase rates and $\mathrm{Si}(\mathrm{OH})_{4}$ concentration}

Total aminopeptidase activity was always lower when the pressure was increased over time than at
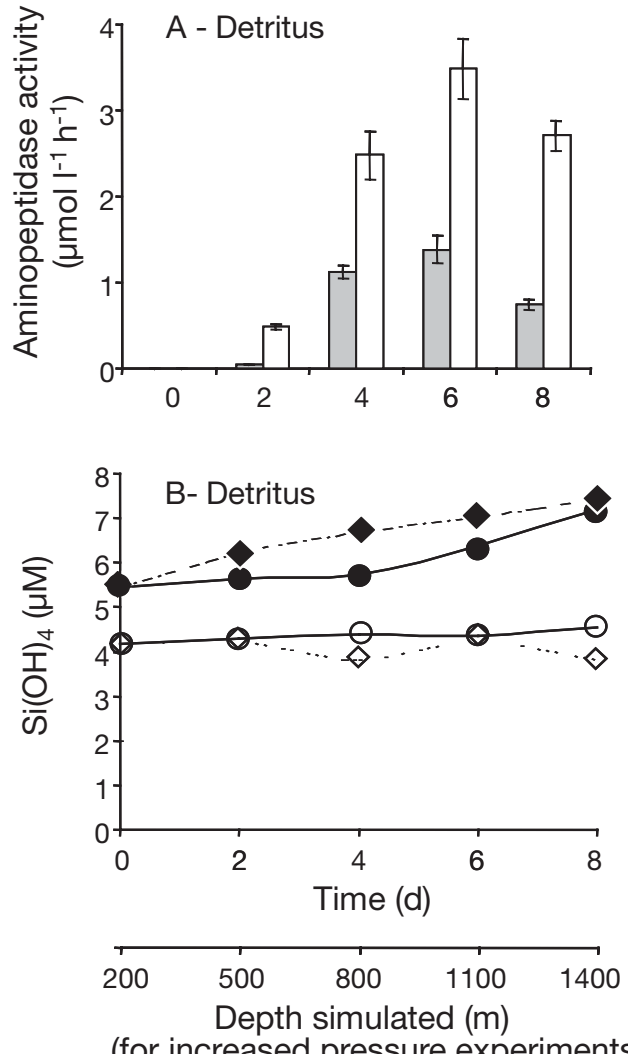

(for increased pressure experiments)

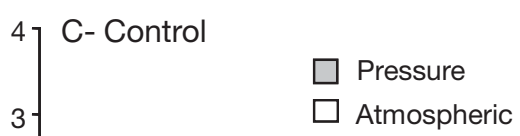

Atmospheric

Fig. 2. (A,C) Aminopeptidase rates and $(B, D)$ orthosilicic acid $\left[\mathrm{Si}(\mathrm{OH})_{4}\right]$ concentrations over time. Natural prokaryotic assemblages were incubated with fresh diatom detritus (A,B: Detritus) and without detritus (C,D: Control). Aminopeptidase activity was measured under increasing hydrostatic pressure conditions to simulate pressure experienced at a sinking rate of $150 \mathrm{~m}$ $\mathrm{d}^{-1} \quad\left(1.5 \mathrm{MPa} \quad \mathrm{d}^{-1}\right)$ and under atmospheric pressure. $\mathrm{Si}(\mathrm{OH})_{4}$ concentrations were measured under increasing hydrostatic pressure conditions and under atmospheric pressure. Under sterilized conditions, $\mathrm{Si}(\mathrm{OH})_{4}$ concentrations were measured under increasing hydrostatic pressure conditions and under atmospheric pressure. Sampling date: February 2004 
atmospheric pressure (Fig. 2A). During the incubation with diatom detritus, aminopeptidase rates increased from $0.15 \mu \mathrm{mol}$ MCA-Leu hydrolyzed $\mathrm{l}^{-1} \mathrm{~h}^{-1}$ at Time 0 to $1.39 \mu \mathrm{mol}$ MCA-Leu hydrolyzed $\mathrm{l}^{-1} \mathrm{~h}^{-1}$ at Day 6 , when the pressure was $11 \mathrm{MPa}(1100 \mathrm{~m}$ simulated depth), 2.5-fold lower than the atmospheric control.

The second experiment confirmed that aminopeptidase activity under increasing pressure was lower than at atmospheric pressure (Fig. 3A). The differences in aminopeptidase activity were due to differences in cell-specific activity (amol cell ${ }^{-1} \mathrm{~h}^{-1}$ ) rather than in the abundance of prokaryotes. Aminopeptidase rates were 6.3 to $311.3 \mathrm{amol} \mathrm{cell}^{-1} \mathrm{~h}^{-1}$ as the pressure increased over time, around half the rates at atmospheric pressure (10.1 to $\left.508.7 \mathrm{amol} \mathrm{cell}^{-1} \mathrm{~h}^{-1}\right)$.

During the first $4 \mathrm{~d}$ of incubation, $\mathrm{Si}(\mathrm{OH})_{4}$ concentrations were higher in the atmospheric pressure incubation than in the incubation with increasing pressure, in both experiments (Figs. 2B \& 3B). The initial silicic acid regeneration rates were very low $\left(0.07 \pm 0.02 \mu \mathrm{mol} \mathrm{l} \mathrm{l}^{-1}\right.$ $\mathrm{h}^{-1}$ ) during the first $4 \mathrm{~d}$ of incubation under increasing pressure (simulating a fall of particles between 200 and $800 \mathrm{~m}$ ), whereas rates under atmospheric pressure conditions were easily measured $\left(0.32 \pm 0.05 \mu \mathrm{mol} \mathrm{l} \mathrm{l}^{-1}\right.$ $\left.\mathrm{h}^{-1}\right)$. However, $\mathrm{Si}(\mathrm{OH})_{4}$ concentrations in the increasing pressure incubations approached those of the atmospheric pressure incubations by the end of the experiment. Overall, rates were $0.21 \pm 0.05$ and $0.24 \pm$ $0.03 \mu \mathrm{mol} \mathrm{l} \mathrm{l}^{-1} \mathrm{~h}^{-1}$ under increasing pressure and atmospheric pressure conditions, respectively, at the end of the first experiment (Fig. 2B) and $0.70 \pm 0.08$ and $0.68 \pm$ $0.29 \mu \mathrm{mol} \mathrm{l} \mathrm{l}^{-1} \mathrm{~h}^{-1}$, respectively, at the end of the second experiment (Fig. 3B).

Two controls were performed: one with sterilized seawater and diatom detritus and the other in the same seawater without fresh diatom detritus. $\mathrm{Si}(\mathrm{OH})_{4}$ concentrations did not change under atmospheric pressure or under increasing pressure over time in these controls.

\section{Response of prokaryotic community structure to pressure and diatom detritus}

At the beginning of the incubation, the prokaryotic community consisted of $17 \%$ of the CytophagaFlavobacter cluster, $23 \%$ of $\alpha$-Proteobacteria and $33 \%$ of $\gamma$-Proteobacteria, and $25 \%$ of Crenarchaea and $13 \%$ of Euryarchaea (Fig. 4). From Day 2, Bacteria were dominant (close to 90\%) among prokaryotes, increasing 2-fold from Day 0. In contrast, Archaea (Crenarchaea and Euryarchaea) drastically decreased to negligible levels by the end of the incubation. Crenarchaea represented $<2 \%$ of total prokaryotes and Euryarchaea $<0.5 \%$ of total prokaryotes.
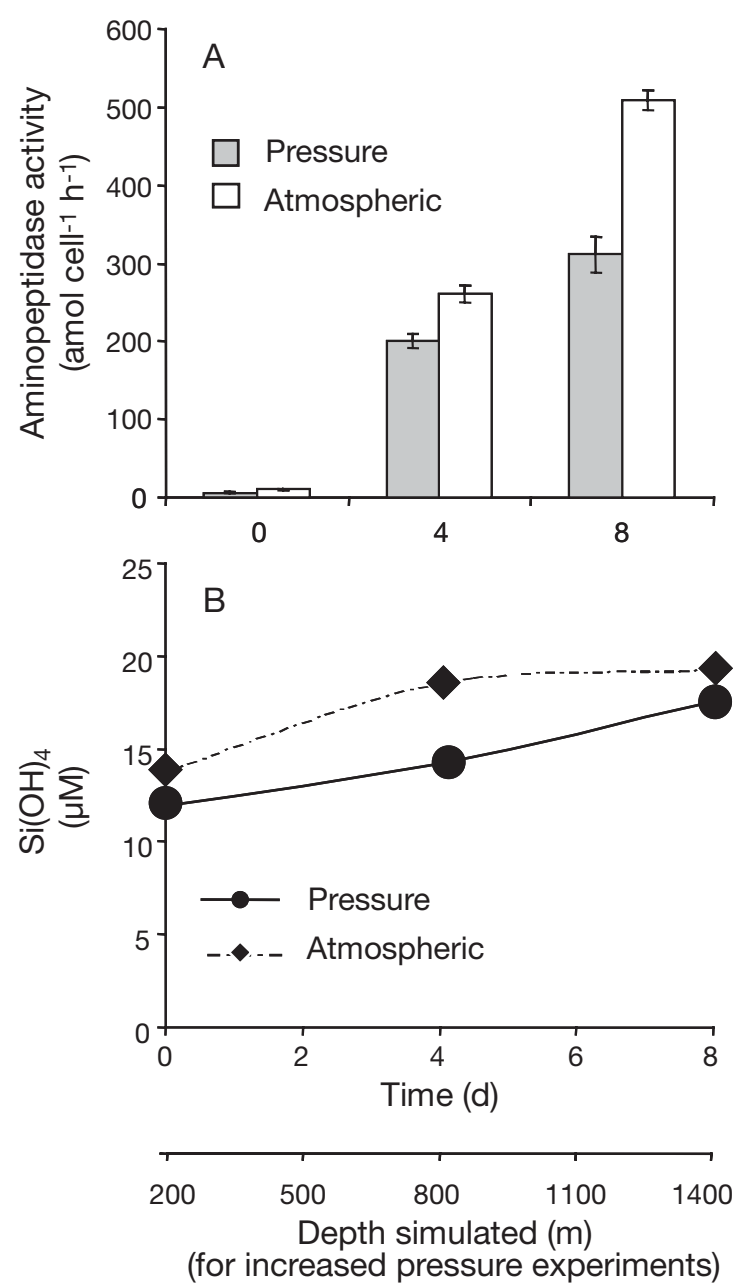

Fig. 3. Cell-specific (A) aminopeptidase rates and (B) $\mathrm{Si}(\mathrm{OH})_{4}$ concentrations over time. Natural prokaryotic assemblages were incubated with detritus under increasing hydrostatic pressure conditions simulating a particle fall of $150 \mathrm{~m} \mathrm{~d}^{-1}(1.5$ $\mathrm{MPa} \mathrm{d}^{-1}$ ) and under atmospheric pressure. Sampling date: January 2002

Among the Bacteria, the Cytophaga-Flavobacter cluster appeared to dominate in incubations with diatom detritus; this cluster was always more numerous and constituted a higher percentage of the total prokaryotes than the $\gamma$-Proteobacteria group, which was the second most abundant group. Without detritus, the $\gamma$-Proteobacteria group dominated the first half of the incubation (Days 0 to 4), but drastically decreased after Day 4, when the CytophagaFlavobacter cluster became dominant until the end of the incubation. Community structure changed under increasing pressure conditions in a fashion similar to how it changed in the atmospheric pressure condition treatment. Whatever the conditions, the $\alpha$-Proteobacteria group appeared negligible from Day 2, constituting $<3 \%$ of the total prokaryotes. 


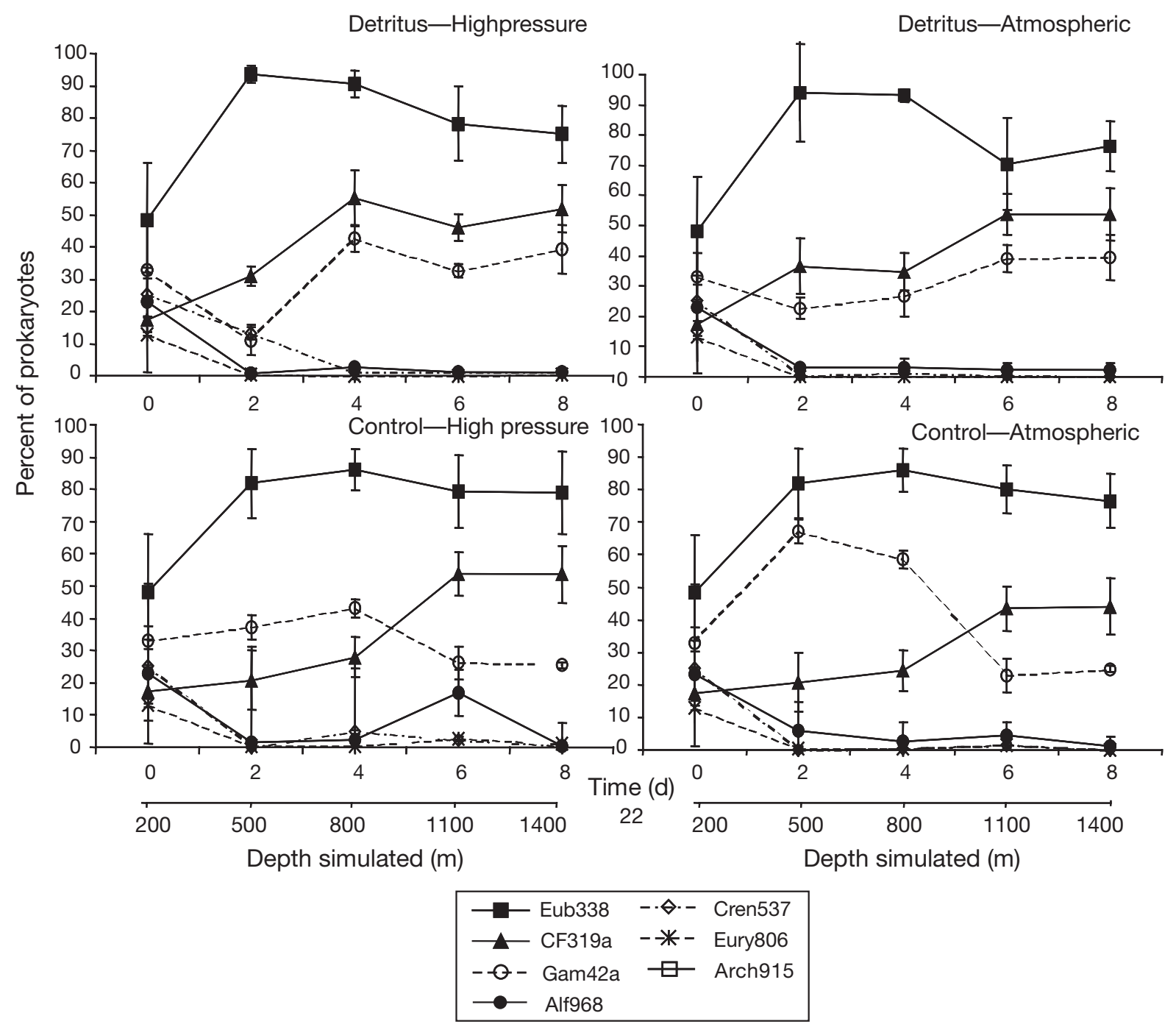

Fig. 4. Percent of total prokaryotes (DAPI-stained cells) detected by fluorescence in situ hybridization over time. Detritus-High pressure: incubation with fresh diatom detritus under increasing hydrostatic pressure conditions; Detritus-Atmospheric: incubation with detritus at atmospheric pressure; Control- High pressure: incubation without detritus under increasing hydrostatic pressure conditions; Control-Atmospheric: incubation without detritus at atmospheric pressure; Eub338: Bacteria; CF319a: Cytophaga-Flavobacter cluster of the Cytophaga-Flavobacter-Bacteroides division; Gam42a, Alf968: $\gamma$-subclass and $\alpha$-subclass of Proteobacteria; Cren537: Crenarchaea; Eury806: Euryarchaea; Arch915: Archaea. Sampling date: February 2004

\section{DISCUSSION}

When diatoms die, they tend to aggregate and sink through the water column (Alldredge et al. 1995). Because it is difficult to follow in situ degradation of organic matter and regeneration of biogenic elements considered as mineral ballast (e.g. silica, calcium carbonates, and dust), we designed an experiment to simulate the sinking of diatom detritus. Our experimental design was based on that of Bidle \& Azam $(1999,2001)$ and Bidle et al. $(2002,2003)$, changing only 1 parameter: the pressure. Temperature was maintained at $13^{\circ} \mathrm{C}$, which corresponds to the temperature in the mesopelagic and bathypelagic zones of the Mediterranean. A gradual increase in pressure was applied to surface water samples during the incubation. This pressure increase corresponded to a sinking rate of 150 $\mathrm{m} \mathrm{d}^{-1}$. This sinking rate is well within the vast range of rates reported in the literature. For example, Smayda (1970) gave a settling range for the phytoplankton of 1 to $510 \mathrm{~m} \mathrm{~d}^{-1}$. Shanks \& Trent (1980) calculated a sinking rate for marine snow of between 43 and $95 \mathrm{~m} \mathrm{~d}^{-1}$ (with a mean of $68 \mathrm{~m} \mathrm{~d}^{-1}$ ), while McCave (1975) estimated a sinking rate of $105 \mathrm{~m} \mathrm{~d}^{-1}$. Other field and experimental studies report values ranging from 1 to $370 \mathrm{~m} \mathrm{~d}^{-1}$ (see references in Alldredge et al. 1995). 
All measurements were done on the entire prokaryotic community, not just on the prokaryotes firmly attached to the diatom detritus, because it was impossible to separate free from attached bacteria in these experiments. In any case, there is a tight coupling between particle fluxes and free-living prokaryotes (Cho \& Azam 1988, Nagata et al. 2000). Moreover, sinking particles are surrounded by a plume of nutrients, carbon, and microbes that can create hotspots of growth and carbon cycling by free-living bacteria (Kiørboe \& Jackson 2001, Long \& Azam 2001). Also, in the experiments of this study, it seems likely that pressure affected both free-living and attached bacteria. Turley (1993) demonstrated that both free-living bacteria and bacteria attached to sinking particles were affected by pressure increases.

The results indicate that increasing hydrostatic pressure significantly affected the aminopeptidase activity of prokaryotic populations during our incubation under increasing pressure conditions and certainly when particles were sinking. In fact, the activity rates were always lower under increasing pressure than under atmospheric pressure. This low aminopeptidase activity was associated with low initial silicic acid regeneration rates, consistent with the results of Bidle \& Azam (1999, 2001). These previous studies hypothesized that regeneration of silicic acid from diatom detritus depends on hydrolysis of proteins in the silicic acid-protein matrix of the frustrales. However, eventually silicic acid concentrations under pressure approached those observed in the atmospheric pressure incubation, although aminopeptidase activity did not, suggesting that even low aminopeptidase activity is sufficient to eventually release silicic acid from diatom frustrales. These results suggest some degree of uncoupling between organic material degradation and silicic acid regeneration as particles sink through the water column. Experiments on diatom aggregates at atmospheric pressure have shown that dissolution rates of silica are lower for aggregated cells than for dispersed cells (Passow et al. 2003). Organic substances might chemically protect diatom frustules within aggregates and reduce dissolution by prokaryotic activity. Our data showing that pressure decreases ectoenzymatic activity suggest that dissolution rates are reduced when diatoms embedded within sinking aggregates fall through the water column.

It is well known that major environmental variables, such as temperature (Ward et al. 1998), nutrient status (Broughton \& Gross 2000), pollutants (Muller et al. 2001, Castle \& Kirchman 2004), and predation (Jürgens \& Matz 2002) influence the composition of prokaryotic communities. To our knowledge, this is the first study to examine the effect of pressure on the structure of prokaryotic communities. Results from
FISH and denaturing gradient gel electrophoresis (data not shown) indicated that increasing pressure did not affect prokaryotic community structure any differently than constant atmospheric pressure during the 8 d of incubation. However, Archaea decreased in all incubations as soon as the experiment started. These results are consistent with those from previous experiments carried out on surface samples, suggesting that Archaea do not play a significant role in promoting silicic acid regeneration (Bidle \& Azam 2001). Since our data confirm that Archaea are not enriched on particles in surface waters (Simon et al. 2002), we suggest that the high densities of free-living Archaea found in the deep sea (Delong 1998, Delong et al. 1999, Karner et al. 2001, Church et al. 2003, Teira et al. 2004) are not related to vertical transport by sinking particles.

In parallel treatments with and without increasing pressure, the diatom detritus seemed to have an influence on prokaryotic diversity during the $8 \mathrm{~d}$ of incubation. In particular, the enrichment with axenic diatom detritus stimulated an increase in the relative abundance of the Cytophaga-Flavobacter-Bacteroides group and of the $\gamma$-Proteobacteria, the second most dominant group. These results agree with those of several studies carried out on the diversity of prokaryotic communities degrading organic carbon and nitrogen in diatom aggregates (Bidle \& Azam 2001, Grossart $\&$ Ploug 2001). The Cytophaga-Flavobacter, $\alpha$ Proteobacteria, and $\gamma$-Proteobacteria clusters seem to dominate communities associated with marine snow in oceanic systems (DeLong et al. 1993, Ploug \& Grossart 1999, Simon et al. 2002) and in the Mediterranean Sea (Acinas et al. 1999, Moeseneder et al. 2001). Using FISH, Ploug \& Grossart (1999) showed that members of the Cytophaga-Flavobacter cluster constituted around $30 \%$ of the DAPI-stained cells on marine snow in the Southern California Bight. Bidle \& Azam (2001) also analyzed the bacterial community on aggregates of diatom detritus incubated with a natural bacterial assemblage in coastal waters off California by denaturing gradient gel electrophoresis and found a dominance of the $\gamma$-Proteobacteria and CytophagaFlavobacter clusters. These observations are consistent with other studies, suggesting that, although the Cytophaga-Flavobacter and $\gamma$-Proteobacteria clusters play a major role in the degradation of high molecular weight organic carbon (Cottrell \& Kirchman 2000b, Kirchman 2002), $\alpha$-Proteobacteria seems to dominate uptake of low molecular weight material (Cottrell \& Kirchman 2000a, Malmstrom et al. 2005).

This study found that organic matrix hydrolysis and silica dissolution are influenced by pressure as diatoms and associated prokaryotes fall through the water column. This initial study focused on a single factor (pressure) and its effect on the remineralization of sinking 
particles. The instrumentation used in this study can be modified to examine the other factors, such as temperature, that may affect detritus degradation and silica dissolution. However, this initial study should help us to understand the role of prokaryotes in the mineralization of organic matter and their contribution to regeneration of the mineral ballast (e.g. silica and carbonates). This information is essential for improving models to describe organic matter mineralization by prokaryotes and the transfer of carbon and energy to the dark ocean and for exploring the consequences of these processes in the global carbon cycle. Moreover, the strategy proposed in this study will provide us with useful information about links between the structure and function of the bacterial compartment involved in the transfer of organic carbon from the surface to the deep layers of the water column.

Acknowledgements. This work was funded by the Institut National des Sciences de l'Univers with the PROOF-SINPAS (see www.com.univ-mrs.fr/LMGEM/sinpas) program (awarded to C.T.) and the DOE BIOMP program (awarded to D.L.K.). We thank M. Cottrell for skillful assistance and his development of image analysis for FISH, L. Yu and the rest of the Kirchman laboratory. We also thank B. Quéguiner for his help with the silicic acid analysis. C.T. is especially grateful to Armand Bianchi, to whom this article is dedicated, for his continuous support and his valuable scientific insights. We also thank L. Giuliano and D. Lefèvre for helpful comments and discussion of the manuscript.

\section{LITERATURE CITED}

Acinas SG, Anton J, Rodriguez-Valera F (1999) Diversity of free-living and attached bacteria in offshore western Mediterranean waters as depicted by analysis of genes encoding 16S rRNA. Appl Environ Microbiol 65:514-522

Alldredge AL, Gotschalk C (1988) In situ settling behaviour of marine snow. Limnol Oceanogr 33:339-351

Alldredge AL, Gotschalk C, Passow U, Riebesell U (1995) Mass aggregation of diatom blooms: insights from a mesocosm study. Deep-Sea Res II 42:9-27

Amann RI, Binder BJ, Olson RJ, Chisholm SW, Devereux R, Stahl DA (1990) Combination of 16S rRNA-targeted oligonucleotide probes with flow cytometry for analyzing mixed microbial populations. Appl Environ Microbiol 56: 1919-1925

Armstrong RA, Lee C, Hedges JI, Honjo S, Wakeham SG (2002) A new, mechanistic model for organic carbon fluxes in the ocean, based on the quantitative association of POC with ballast minerals. Deep-Sea Res II 49:219-236

Bianchi A, Garcin J (1993) In stratified waters the metabolic rate of deep-sea bacteria decreases with decompression. Deep-Sea Res I 40:1703-1710

Bianchi A, Garcin J, Tholosan O (1999) A high-pressure serial sampler to measure microbial activity in the deep sea. Deep-Sea Res I 46:2129-2142

Bidle KD, Azam F (1999) Accelerated dissolution of diatom silica by marine bacterial assemblages. Nature 397:508-512

Bidle KD, Azam F (2001) Bacterial control of silicon regeneration from diatom detritus: significance of bacterial ecto- hydrolases and species identity. Limnol Oceanogr 46: 1606-1623

Bidle KD, Manganelli M, Azam F (2002) Regulation of oceanic silicon and carbon preservation by temperature control on bacteria. Science 298:1980-1984

Bidle KD, Brzezinski MA, Long RA, Jones JL, Azam F (2003) Diminished efficiency in the oceanic silica pump caused by bacterially-mediated silica dissolution. Limnol Oceanogr 48:1855-1868

Broughton LC, Gross KL (2000) Patterns of diversity in plant and soil microbial communities along a productivity gradient in a Michigan old-field. Oecologia 125:420-427

Castle D, Kirchman DL (2004) Composition of estuarine bacterial communities assayed by denaturing gradient gel electrophoresis and fluorescence in situ hybridization. Limnol Oceanogr 2:303-314

Cho BC, Azam F (1988) Major role of bacteria in biogeochemical fluxes in the ocean's interior. Nature 332:441-443

Chrost RJ (1991) Environmental control of the synthesis and activity of aquatic microbial ectoenzymes. In: Chrost RJ (ed) Microbial enzymes in aquatic environments. Springer-Verlag, New York, p 29-59

Church MJ, Delong EF, Ducklow HW, Karner MB, Preston CM, Karl DM (2003) Abundance and distribution of planktonic Archaea and Bacteria in the waters west of the Antarctic Peninsula. Limnol Oceanogr 48:1893-1902

Cottrell MT, Kirchman DL (2000a) Community composition of marine bacterioplankton determined by $16 \mathrm{~S}$ rRNA gene clone libraries and fluorescence in situ hybridization. Appl Environ Microbiol 66:5116-5122

Cottrell MT, Kirchman DL (2000b) Natural assemblages of marine proteobacteria and members of the CytophagaFlavobacter cluster consuming low- and high-molecularweight dissolved organic matter. Appl Environ Microbiol 66:1692-1697

Cottrell MT, Kirchman DL (2003) Contribution of major bacterial groups to bacterial biomass production (thymidine and leucine incorporation) in the Delaware estuary. Limnol Oceanogr 48:168-178

DeLong E (1998) Archaeal means and extremes. Science 280: 542-543

DeLong EF, Franks DG, Alldredge AL (1993) Phylogenetic diversity of aggregate-attached vs. free-living marine bacteria assemblages. Limnol Oceanogr 38:924-934

DeLong EF, Taylor LT, Marsh TL, Preston CM (1999) Visualization and enumeration of marine planktonic archaea and bacteria by using polyribonucleotide probes and fluorescent in situ hybridization. Appl Environ Microbiol 65: $5554-5563$

Deming JW (2001) Unusual or extreme high-pressure marine environments. In: Hurst CJ, Knudsen GR, McInerney MJ, Stetzenbach LD, Walter MV (eds) ASM manual of environmental microbiology, 2nd edn. ASM Press, Washington, DC, p 478-490

Dugdale RC, Wilkerson FP (1998) Silicate regulation of new production in the equatorial Pacific upwelling. Nature 391:270-273

Eilers H, Pernthaler J, Glockner FO, Amann R (2000) Culturability and in situ abundance of pelagic bacteria from the North Sea. Appl Environ Microbiol 66:3044-3051

Francois R, Honjo S, Krishfield R, Manganini S (2002) Factors controlling the flux of organic carbon to the bathypelagic zone of the ocean. Global Biogeochem Cycles 16: $1087-1106$

Glöckner FO, Amann R, Alfreid J, Pernthaler J, Psenner R, Tresebius K, Schleifer KH (1996) An in situ hybridization protocol for detection and identification of planktonic 
bacteria. Syst Appl Microbiol 19:403-406

Glöckner FO, Fuchs BM, Amann R (1999) Bacterioplankton compositions of lakes and oceans: a first comparison based on fluorescence in situ hybridization. Appl Environ Microbiol 65:3721-3726

Grossart HP, Ploug H (2001) Microbial degradation of organic carbon and nitrogen on diatom aggregates. Limnol Oceanogr 46:267-277

Guillard RRL (1975) Culture of phytoplankton for feeding marine invertebrate animals. In: Smith WL, Chanley $\mathrm{MH}$ (eds) Culture of marine invertebrate animals. Plenum Press, New York, p 29-60

Hedges JI, Eglinton G, Hatcher PG, Kirchman DL and 8 others (2000) The molecularly-uncharacterized component of nonliving organic matter in natural environments. Org Geochem 31:945-958

Honjo S, Dymond J, Collier R, Manganini SJ (1995) Export production of particles to the interior of the equatorial Pacific Ocean during the 1992 EqPac experiment. DeepSea Res II 42:831-870

Jannasch HW, Wirsen CO (1982) Microbial activities in undecompressed microbial populations from deep seawater samples. Appl Environ Microbiol 43:1116-1124

Jürgens K, Matz C (2002) Predation as a shaping force for the phenotypic and genotypic composition of planktonic bacteria. Antonie Leeuwenhoek 81:413-434

Karner M, Fuhrman J (1997) Determination of active marine bacterioplankton: a comparison of universal 16S rRNA probes, autoradiography, and nucleoid staining. Appl Environ Microbiol 63:1208-1213

Karner MB, DeLong EF, Karl DM (2001) Archaeal dominance in the mesopelagic zone of the Pacific Ocean. Nature 409: $507-510$

Kiørboe T, Jackson GA (2001) Marine snow, organic solute plumes, and optimal chemosensory behavior of bacteria. Limnol Oceanogr 46:1309-1318

Kirchman DL (2002) The ecology of Cytophaga-Flavobacteria in aquatic environments. FEMS Microbiol Ecol 39:91-100

Long RA, Azam F (2001) Microscale patchiness of bacterioplankton assemblage richness in seawater. Aquat Microb Ecol 206:103-113

Malmstrom RR, Cottrell MT, Elifantz H, Kirchman DL (2005) Biomass production and assimilation of dissolved organic matter by SAR11 bacteria in the Northwest Atlantic Ocean. Appl Environ Microbiol 71:2979-2986

Manz W, Amann R, Ludwig W, Wagner M, Scheiler KH (1992) Phylogenetic oligodeoxynucleotide probes for the major subclasses of proteobacteria: problems and solution. Syst Appl Microbiol 15:593-600

Manz W, Amann R, Ludwig W, Vancanneyt M, Schleifer KH (1996) Application of a suite of 16S rRNA-specific oligonucleotide probes designed to investigate bacteria of the phylum Cytophaga-Flavobacter-Bacteroides in the natural environment. Microbiology 142(5):1097-1106

Martin JH, Knauer GA, Karl DM, Broenkow WW (1987) VERTEX: carbon cycling in the Northeast Pacific. Deep-Sea Res 34:267-285

McCave (1975) Vertical flux of particles in the ocean. DeepSea Res 22:491-502

Milliman JD, Troy PJ, Balch WM, Adams AK, Li YH, Mackenzie FT (1999) Biologically mediated dissolution of calcium carbonate above the chemical lysocline? Deep-Sea Res I 46:1653-1669

Moeseneder MM, Winter C, Herndl GJ (2001) Horizontal and vertical complexity of attached and free-living bacteria of the eastern Mediterranean Sea, determined by 16S rDNA and 16S rRNA fingerprints. Limnol Oceanogr 46:95-107
Muller AK, Westergaard K, Christensen S, Sorensen SJ (2001) The effect of long-term mercury pollution on the soil microbial community. FEMS Microbiol Ecol 36:11-19

Nagata T, Fukuda H, Fukuda R, Koike I (2000) Bacterioplankton distribution and production in deep Pacific waters: large-scale geographic variations and possible coupling with sinking particle fluxes. Limnol Oceanogr 45:426

Nelson DM, Tréguer $\mathrm{P}$, Brzezinski MA, Leynaert A, Quéguiner B (1995) Production and dissolution of biogenic silica in the ocean: revised global estimates, comparison with regional data and relationship with biogenic sedimentation. Global Biogeochem Cycles 9:359-372

Panagiotopoulos C, Sempéré R, Obernosterer I, Striby L, Goutx M, Van Wambeke F, Gautier S, Lafont R (2002) Bacterial degradation of large particles in the southern Indian Ocean using in vitro incubation experiments. Organic Geochem 33:985-1000

Passow U, Engel A, Ploug H (2003) The role of aggregation for the dissolution of diatom frustules. FEMS Microbiol Ecol 46:247-255

Ploug H, Grossart HP (1999) Bacterial production and respiration in suspended aggregates - a matter of the incubation method. Aquat Microb Ecol 20:21-29

Sempéré R, Yoro SO, Van Wambeke F, Charrière B (2000) Microbial decomposition of large organic particles in the northwestern Mediterranean Sea: an experimental approach. Mar Ecol Prog Ser 198:61-72

Shanks AL, Trent JD (1980) Marine snow: sinking rates and potential role in vertical flux. Deep-Sea Res 27A:137-143

Simon M, Grossart HP, Schweitzer B, Ploug H (2002) Microbial ecology of organic aggregates in aquatic ecosystems. Aquat Microb Ecol 28:175-211

Smayda TJ (1970) The suspension and sinking of phytoplankton in the sea. Oceanogr Mar Biol Annu Rev 8:353-414

Smith CR, Hoover DJ, Doan SE, Pope RH, Demaster DJ, Dobbs FC, Altabet MA (1996) Phytodetritus at the abyssal seafloor across $10^{\circ}$ of latitude in the central equatorial Pacific. Deep-Sea Res II 43:1309-1338

Stahl DA, Amann R (1991) Development and application of nucleic acid probes. In: Stackebrandt E, Goodfellow M (eds) Nucleic acid techniques in bacterial systematics. John Wiley \& Sons, Chichester, p 205-248

Strickland JDH, Parsons TR (1972) A practical handbook of seawater analysis. Bull Fish Res Board Can 167:1-310

Tabor PS, Deming JW, Ohwada K, Davis H, Waxman M, Colwell RR (1981) A pressure-retaining deep ocean sampler and transfer system for measurement of microbial activity in the deep sea. Microb Ecol 7:51-65

Tamburini C, Garcin J, Ragot M, Bianchi A (2002) Biopolymer hydrolysis and bacterial production under ambient hydrostatic pressure through a $2000 \mathrm{~m}$ water column in the NW Mediterranean. Deep-Sea Res II 49:2109-2123

Tamburini C, Garcin J, Bianchi A (2003) Role of deep-sea bacteria in organic matter mineralization and adaptation to hydrostatic pressure conditions in the NW Mediterranean Sea. Aquat Microb Ecol 32:209-218

Teira E, Reinthaler T, Pernthaler A, Pernthaler J, Herndl GJ (2004) Combining catalyzed reporter depositionfluorescence in situ hybridization and microautoradiography to detect substrate utilization by bacteria and Archaea in the deep ocean. Appl Environ Microbiol 70:4411-4414

Tréguer P, Pondaven P (2000) Global change: silica control of carbon dioxide. Nature 406:358-359

Tréguer P, Kamatani A, Gueneley S, Quéguiner B (1989) Kinetics of dissolution of Antarctic diatom frustules and the biogeochemical cycle of silicon in the Southern Ocean. Polar Biol 9:397-403 
Turley CM (1993) The effect of pressure on leucine and thymidine incorporation by free-living bacteria and by bacteria attached to sinking oceanic particles. Deep-Sea Res I 40:2193-2206

Turley CM, Mackie PJ (1994) Biogeochemical significance of attached and free-living bacteria and the flux of particles in the NE Atlantic Ocean. Mar Ecol Prog Ser 115:191-203

Turley CM, Mackie PJ (1995) Bacterial and cyanobacterial flux to the deep NE Atlantic on sedimenting particles. Deep-Sea Res I 42:1453-1474

Wakeham SG, Lee C, Hedges JI, Hernes PJ, Peterson ML (1997) Molecular indicators of diagenetic status in marine

Editorial responsibility: Fereidoun Rassoulzadegan, Villefranche-sur-Mer, France organic matter. Geochim Cosmochim Acta 61:5363-5369 Ward DM, Ferris MJ, Nold SC, Bateson MM (1998) A natural view of microbial biodiversity within hot spring cyanobacterial mat communities. Microbiol Mol Biol Rev 62:221-271

Zarda B, Hahn D, Chatzinotas A, Schönhuber W, Neef A, Amann RI, Zeyer J (1997) Analysis of bacterial community structure in bulk soil by in situ hybridization. Arch Microbiol 168:185-192

ZoBell CE (1970) Pressure effects on morphology and life processes of bacteria. In: Zimmerman HM (ed) High pressure effects on cellular processes. Academic Press, New York, p 85-130

Submitted: December 12, 2005; Accepted: March 20, 2006

Proofs received from author(s): June 22, 2006 